\title{
PELUANG PENGHEMATAN ENERGI PADA BOILER DI PT INDO BHARAT RAYON
}

\author{
Kholiq Hernawan ${ }^{1}$ \\ Jurusan Teknik Konversi Energi, Politeknik Negeri Bandung,Indonesia \\ Email: kholiq.h@gmail.com
}

\begin{abstract}
Abstrak
Boiler adalah suatu bejana tekan dimana air/fluida dipanaskan oleh gas hasil pembakaran. Uap yang dihasilkan digunakan untuk berbagai proses. Boiler juga merupakan pesawat konversi energi yang mengubah energi dari pembakaran menjadi energi yang terkandung dalam uap. Audit boiler bertujuan untuk mengidentifikasi adanya peluang penghematan energy, yang bisa diketahui dari parameter efisiensi. Perhitungan terhadap efisiensi boiler biasanya menggunakan metode langsung dan metode tidak langsung. Perhitungan efisiensi menggunakan metode ASME PTC 4.1. Metode langsung merupakan perhitungan efisiensi boiler secara cepat, hanya membandingkan energy output dengan energy input, sedangkan metode tidak langsung merupakan perhitungan efisiensi boiler dengan memperhitungan rugi rugi atau energy panas yang hilang. Berdasarkan hasil pengukuran dan perhitungan didapatkan efisiensi dengan metode langsung sebesar 80,35\%, sedangkan berdasarkan metode tidak langsung didapatkan efisiensi sebesar 79,68 \% . Jika nilai efisiensi tersebut dibandingkan dengan spesifikasi efesiensi boiler sebesar 86,3 $\%$ maka performansi /efisiensi boiler tesebut sudah mengalami penurunan. Untuk meningkatkan efisiensi boiler tersebut dengan memperbaiki system pembakaran agar mencapai pembakaran sempurna. Untuk mendapatkan pembakaran sempurna dengan memasang Combustion Optimizer. Setelah dilakukan analisa kelayakan, pemasangan Combustion Optimizer layak dilakukan karena memberikan nilai NPV yang positif dan Break Even Point yang singkat ( sebesar 1,6 bulan) dan memberikan penghematan pertahun sebesar Rp 1.155.017.988,0. Investasi yang diperlukan untuk pemasangan Combustion Optimizer sebesar Rp 150 Juta.
\end{abstract}

\section{Kata Kunci: Efisiensi Boiler, Audit Energi, Konservasi Energi, Kelayakan Ekonomi, Combustion Optimizer}

\section{PENDAHULUAN}

Dari segi ekonomi, penggunaan energi merupakan variabel yang cukup besar dalam perhitungan biaya produksi. Penggunaan energi yang tidak efisien menyebabkan biaya tinggi sehingga berpengaruh dalam biaya produksi dan daya saing.

Permasalahan energi menjadi isu yang terus berkembang bagi setiap negara termasuk Indonesia. Hal ini terkait dengan laju peningkatan kebutuhan energi bagi sektor industri, transportasi, bangunan dan rumah tangga (demand side) dan keterbatasan sumber cadangan energi yang sampai saat ini masih tergantung pada energi berbasis fosil (BBM, Gas dan Batubara).

Lebih ironisnya lagi, Indonesia menjadi salah satu negara dengan tingkat elastisitas energi cukup tinggi yang mencapai 1,63 lebih tinggi dibandingkan Thailand dan Singapura yang masingmasing mencapai 1,4 dan 1,1. Bahkan indeks elastisitas energi negara-negara maju berkisar antara 0,1 hingga 0,6 (tingkat elastisitas adalah perbandingan laju pertumbuhan konsumsi energi dibanding laju pertumbuhan ekonomi). [1]

Dari sisi peningkatan kinerja penggunaan energi pada sektor industri, pemerintah telah menetapkan kebijakan konservasi energi sebagaimana tertuang dalam Peraturan Pemerintah No 70 tahun 2009. Dalam kebijakan tersebut, diwajibkan industri pengguna energi dalam jumlah besar (> 6000 toe) untuk menerapkan manajemen energi. [1]

Salah satu industri yang mengkonsumsi energi yang cukup besar adalah Industry Tektil, sehingga pada penelitian ini dilakukan audit energi untuk menemukan peluang penghematan energi pada pabrik tektil PT. Indo Bharat Rayon terutama pada peralatan boilernya, karena peralatan ini mengkonsumsi energy yang terbesar.

PT. Indo Bharat Rayon adalah perusahaan yang bergerak dalam bidang industri tekstil dan memiliki sistem PLTU dengan kapasitas pembangkit $15 \mathrm{MW}$. PLTU dari PT. Indo Bharat Rayon memiliki 3 unit boiler sebagai salah satu komponen utama dalam sistem pembangkit yang berfungsi mengubah air menjadi uap superheat bertemperatur dan bertekanan tinggi sebagai fluida kerja dalam mekanisme penggerak turbin dengan mengandalkan energi kinetik yang dihasilkan dari uap superheat.

Boiler merupakan salah satu komponen penting dalam sistem pembangkit karena akan mempengaruhi kinerja dari sistem pembangkit itu sendiri dan pengkonsumsi energy terbesar. Pengkajian kinerja boiler perlu dilakukan untuk melihat efisien atau tidaknya boiler beroperasi. Konservasi energi pada boiler dirasa perlu dilakukan untuk menunjang penghematan energi.

Audit energy pada boiler diperlukan untuk mengetahui potensi penghematan, sedangkan untuk mengetahui performa/unjuk kerja boiler maka diperlukan pengukuran efisiensi boiler. Efisiensi boiler dapat dihitung dengan metode langsung dan tidak langsung yang mengacu pada standar ASME PTC 4.1.

Hasil perhitungan efisiensi akan dibandingkan dengan standar atau spesifikasi boiler. Konservasi akan dilakukan jika perhitungan efisiensi boiler operasi jauh di bawah standart atau spesifikasi boiler. Sehingga, melakukan konservasi energy akan didapatkan saving/penghematan energy. Studi kasus pada kegiatan ini dilakukan dalam bentuk audit boiler unit 3 pada PT. Indo Bharat Rayon yang kemudian dilakukan perhitungan dan analisis konservasi energi.

\section{TINJAUAN PUSTAKA}

\section{II.1 Efisiensi Boiler}

Terdapat dua metode pengkajian efisiensi boiler:

1. Metode Langsung

2. Metode Tidak Langsung 
Standar acuan untuk menghitung efisiensi boiler menggunakan USA Standart (ASME PTC 4.1 Power Test Code Steam Generating Units).

\section{* Metode Langsung (Metode Direct) [2]}

Metode ini merupakan pendekatan yang dilakukan dengan mengukur jumlah panas yang terdapat pada uap dan membandingkannya dengan jumlah panas yang diberikan bahan bakar. Metode ini dikenal dengan metode 'input-output.

$$
\begin{aligned}
& \eta_{\text {boiler }}=\frac{\dot{\mathrm{m}}_{\text {steam }}\left(h_{\text {steam }}-h_{\text {feedwater }}\right)}{\dot{\mathrm{m}}_{\text {fuel }} x G C V_{\text {fuel }}} \\
& \text { Keterangan: } \\
& \eta_{\text {boiler }}=\text { efisiensi boiler }(\%) \\
& \dot{\mathrm{m}}_{\text {steam }}=\text { laju alir uap }(\mathrm{kg} / \mathrm{jam}) \\
& h_{\text {steam }} \quad=\text { entalpi uap }\left(\mathrm{h}_{\mathrm{g}}\right)(\mathrm{kj} / \mathrm{kg}) \\
& h_{\text {feedwater }}=\text { entalpi air umpan }\left(\mathrm{h}_{\mathrm{f}}\right)(\mathrm{kj} / \mathrm{kg}) \\
& m_{\text {fuel }}=\text { laju alir bahan bakar }(\mathrm{kg} / \mathrm{jam}) \\
& G C V_{\text {fuel }} \quad=\text { nilai kalor bahan bakar }(\mathrm{kj} / \mathrm{kg})
\end{aligned}
$$

\section{* Metode Tidak Langsung (Metode Indirect) [2]}

Merupakan pendekatan yang dilakukan untuk mendapatkan nilai efisiensi dengan mengukur jumlah potensial panas bahan bakar dan menguranginya dengan losses yang terdapat pada boiler.

Metode perhitungan efisiensi secara tidak langsung atau metode kehilangan panas dapat dilihat pada persamaan berikut:

$$
\eta_{\text {boiler }}=100-(L 1+L 2+L 3+L 4+L 5+L 6+L 7+L 8)
$$

Keterangan:

$\eta_{\text {boiler }}=$ efisiensi boiler $(\%)$

L1 = Rugi-rugi gas buang kering (panas sensible)

L2 = Rugi-rugi steam dalam bahan bakar $\left(\mathrm{H}_{2}\right)$

L3 = Rugi-rugi kandungan air bahan bakar $\left(\mathrm{H}_{2} \mathrm{O}\right)$

L4 = Rugi-rugi kandungan air di udara pembakaran $\left(\mathrm{H}_{2} \mathrm{O}\right)$

L5 = Rugi-rugi pembakaran tidak sempurna (CO)

L6 = Rugi-rugi radiasi permukaan, konveksi,

L7 = Rugi-rugi karena fly ash

L8 = Rugi-rugi karena bottom ash

Tahapan dalam perhitungan efisiensi boiler dengan metode tidak langsung dapat di gambarkan dalam tahapan berikut:

Tahap -1 . Kebutuhan udara teoritis [2]

Udara teoritis untuk pembakaran sempurna adalah

$\frac{(11,6 \times C)+\left(34,8 \times\left(H_{2}-\frac{O_{2}}{8}\right)\right)+(4,35 \times S)}{100}$

Tahap - 2. Teoritis $\mathrm{CO}_{2} \%$ pembakaran sempurna

$\% \mathrm{CO}$ pada $=\frac{\text { moles of } \mathrm{C}}{\text { moles } \mathrm{N}_{2}+\text { moles of } \mathrm{C}}$

dimana :

MolesN $N_{2}=\frac{\text { Wt of } \mathrm{N}_{2} \text { in theoritical air }}{\text { mol.Wt of } \mathrm{N}_{2}}+\frac{\text { Wt of } \mathrm{N}_{2} \text { in } \text { fuel }}{\text { mol.Wt of } \mathrm{N}_{2}}$

Tahap - 3 . Persen kelebihan udara yang dipasok (EA) [2]

$\%$ suplai udara berlebih adalah

$7900 x\left[\left(\mathrm{CO}_{2} \%\right)_{t}-\left(\mathrm{CO}_{2} \%\right)_{a}\right]$

$\left(\mathrm{CO}_{2} \%\right)_{a} \times\left[\left(100-\left(\mathrm{CO}_{2} \%\right)_{t}\right)\right]$

Tahap-4. Massa udara sebenarnya yang dipasok (AAS) [2]

Massa sebernarnya $=\left(1+\frac{E A}{100}\right) \times$ udara teoritis

Tahap -5 . Massa aktual gas buang kering[2]

Massa gas buang kering = massa of $\mathrm{CO}_{2}+$ mass of $\mathrm{N}_{2}$ content in the fuel + Mass of $N_{2}$ in the combustion air supplied + mass of oxygen in flue gas

Tahap -6 . losses yang terjadi pada boiler [2]

Heat loss karena gas buang kering ( L1)
Ini merupakan kehilangan terbesar yang dapat dihitung dengan rumus berikut:

$$
L 1 \frac{\dot{m} x C p x\left(T_{f}-T_{a}\right)}{\text { GCV batu bara }} \times 100
$$

Keterangan :

$\dot{\mathrm{m}} \quad=$ massa dry flue gas $(\mathrm{kg} / \mathrm{kg}$ batubara $)$

$\mathrm{Cp}=$ panas spesifik flue gas $=0,23 \mathrm{kCal} / \mathrm{kg}^{0} \mathrm{C}$

Tf = temperatur flue gas $\left({ }^{0} \mathrm{C}\right)$

$\mathrm{Ta}=$ temperatur ambient $\left({ }^{\circ} \mathrm{C}\right)$

$\mathrm{GCV}=$ nilai kalor atas bahan bakar $(\mathrm{kkal} / \mathrm{kg})$

Heat loss karena steam dalam gas buang (L2 ) [2]

Pembakaran hidrogen menyebabkan hilangnya panas karena produk dari pembakaran adalah air. Air ini akan diubah menjadi uap dan akan membawa panas pergi dalam bentuk panas laten

$$
L 2=\frac{9 \times H_{2} \times\left\{584+C p\left(T_{f}-T_{a}\right)\right\}}{G C V \text { batu bara }} \times 100
$$

Keterangan :

$\mathrm{H}_{2} \quad$ = persen massa hydogen dalam $1 \mathrm{~kg}$ bahan bakar $(\mathrm{kg})$

$\mathrm{Cp}=$ panas spesifik superheater $=0,45 \mathrm{kCal} / \mathrm{kg}{ }^{0} \mathrm{C}$

$\mathrm{Tf} \quad=$ temperatur flue gas $\left({ }^{0} \mathrm{C}\right)$

$\mathrm{Ta}=$ temperatur ambient $\left({ }^{\circ} \mathrm{C}\right)$

$\mathrm{GCV}=$ nilai kalor atas bahan bakar $(\mathrm{kCal} / \mathrm{kg})$

Heat loss karena kandungan air bahan bakar $\left(\mathrm{H}_{2} \mathrm{O}\right)$ ( $\mathrm{L} 3$ )[2]

Hilangnya kelembapan ini karena panas sensibel yang membawa uap air pada titik pemanasan, panas laten dari penguapan air yang mendidih, dan panas superheat yang diperlukan dalam membawa uap ini dengan temperatur dari gas buang. Kerugian ini dapat dihitung dengan rumus sebagai berikut :

$$
L 3=\frac{M \times\left\{584+C p\left(T_{f}-T_{a}\right)\right.}{G C V \text { batu bara }} \times 100
$$

Keterangan :

$\mathrm{M}=$ massa embun dalam bahan bakar $1 \mathrm{~kg}$ basis $(\mathrm{kg})$

$\mathrm{Cp} \quad=$ panas spesifik superheater $=0,45 \mathrm{kCal} / \mathrm{kg}{ }^{0} \mathrm{C}$

Tf = temperatur flue gas $\left({ }^{\circ} \mathrm{C}\right)$

$\mathrm{Ta}=$ temperatur ambient $\left({ }^{0} \mathrm{C}\right)$

$\mathrm{GCV}=$ nilai kalor atas bahan bakar $(\mathrm{kkal} / \mathrm{kg})$

Heat loss karena kandungan air di udara $\mathrm{H}_{2} \mathrm{O}$ ( L4)

Uap yang terbentuk karena kelembapan udara yang masuk merupakan superheat saat melewati boiler. Karena panas ini melewati cerobong, maka ini merupakan suatu losses pada boiler. Untuk menghubungkan kerugian ini dengan massa batubara yang dibakar, kandungan kelembapan udara pembakaran dan jumlah udara yang dipasok per satuan massa batubara yang dibakar harus diketahui.

$$
L 4=\frac{\text { AAS } x \text { humidity factor } x C_{p} \times\left(T_{f}-T_{a}\right)}{\text { GCV batu bara }} \times 100
$$

Keterangan :

$\mathrm{AAS}=$ massa udara aktual yang disuplai $(\mathrm{kg})$

$\mathrm{Cp} \quad=$ panas spesifik superheater $\left(\mathrm{kkal} / \mathrm{kg}{ }^{0} \mathrm{C}\right)$

$\mathrm{Tf} \quad=$ temperatur flue gas $\left({ }^{0} \mathrm{C}\right)$

$\mathrm{Ta}=$ temperatur ambient $($ dry-bulb $)\left({ }^{0} \mathrm{C}\right)$

$\mathrm{GCV}=$ nilai kalor atas bahan bakar $(\mathrm{kkal} / \mathrm{kg})$

Humidity faktor = massa air yang terkandung dalam setiap kilogram udara kering $(\mathrm{kg})$

Heat loss karena pembakaran tidak sempurna ( L5 )[2]

Rugi-rugi ini disebabkan oleh bahan yang tidak terbakar dalam residu. Hasil pembentukan dari pembakaran tidak sempurna bisa dicampur dengan oksigen dan dibakar kembali dengan keluaran lebih lanjut dari energi seperti gas buang boiler. produk boiler termasuk $\mathrm{CO}, \mathrm{H}_{2}$, dan berbagai hidrokarbon merupakan satusatunya gas hasil konsentrasi yang dapat ditentukan dalam suatu tes pabrik boiler.

$$
L 5=\frac{\% \mathrm{CO} \times \mathrm{C}}{\% \mathrm{CO}+\% \mathrm{CO}_{2}} \times \frac{5744}{\text { GCV batubara }} 100
$$


Ketika CO dalam ppm selama analisis gas buang

$\mathrm{L} 5=\mathrm{CO}$ (in ppm) $\times 10^{-6} \times \mathrm{M}_{\mathrm{f}} \times 28 \times 5744$

Keterangan :

$\mathrm{CO}=$ volume $\mathrm{CO}$ di flue gas yang meninggalkan ekonomizer

$\mathrm{CO}_{2}=$ volume $\mathrm{CO}_{2}$ aktual di flue gas

$\mathrm{C} \quad$ = kandungan karbon dalam $\mathrm{kg}$ batubara $(\mathrm{kg})$

$\mathrm{GCV}=$ nilai kalor atas bahan bakar $(\mathrm{kCal} / \mathrm{kg})$

$\mathrm{M}_{\mathrm{f}} \quad=$ konsumsi bahan bakar $(\mathrm{kg} / \mathrm{h})$

Heat loss karena radiasi permukaan, konveksi, dan yang tak terhitung ( L6 )[2]

Jika area permukaan boiler dan suhu permukaan boiler diketahui, maka kita dapat menggunakan seperti berikut.

$$
\begin{gathered}
L 6=0,548 x\left[\left(\frac{T_{s}}{55,55}\right)^{4}-\left(\frac{T_{a}}{55,55}\right)^{4}\right]+1,957 x \\
\left(T_{s}-T_{a}\right)^{1,25} x \text { sqrt of }\left[\frac{196,85 V_{m}+68,9}{68,9}\right]
\end{gathered}
$$

Heat loss karena fly ash dan bottom ash [2]

Rugi-rugi karena abu terbang (fly ash) (\%)

$L 7=$

$\frac{\text { total abu per } \mathrm{kg} \text { bahan bakar terbakar } \mathrm{t} \times \mathrm{GCV} \text { of fly ash }}{\text { GCV batu bara }} \times 100$

Rugi-rugi karena abu dasar (bottom ash) \% total abu per $\mathrm{kg}$ bahan bakar terbakar $t x$

$L 8=\frac{G C V \text { of bottom ash }}{\text { GCV batu bara }} \times 100$

\section{II.2 Analisa Kelayakan Ekonomi [4]}

Metode -metode kelayakan ekonomi,antara lain

\section{Net Present Velue (NPV)}

Metode NPV diperoleh dengan mengurangi nilai peluang penghematan energi dengan nilai investasi. Dengan metode ini kelayakan suatu rencana investasi atau pemilihan alternatif di masa depan harus dinyatakan ke dalam nilai sekarang yang ekuivalen dengan suatu tingkat suku bunga yang dijadikan dasar perbandingan. NPV bernilai positif merupakan syarat dilakukannya proyek.

$\mathrm{NPV}=P V$ benefit $-P V$ cost

$\mathrm{NPV}=$ saving $(P / A, i, n)-$ investasi

Dimana :

$\mathrm{i}=$ suku bunga

$\mathrm{n}=$ umur proyek

(P/A , i , n) didapat dari tabel suku bunga.

\section{* Simple Payback Period (SPB)}

Metode ini disebut juga sebagai break event point (BEP) yang dilakukan dengan mengukur waktu yang dibutuhkan untuk mengembalikan investasi awal dalam ukuran penghematan energi. Dapat dihitung dengan cara membagi nilai investasi dengan nilai peluang penghematannya atau saving energy.

$$
\text { Break Event Point }=\frac{\text { investasi }}{\text { saving energy }}
$$

\section{II.3 Metodologi Penelitian}

Penelitian ini dilakukan dalam beberapa tahapan untuk mencapai tujuan penelitian. Adapun tahapan penelitian dapat dilihat pada flowchart berikut.

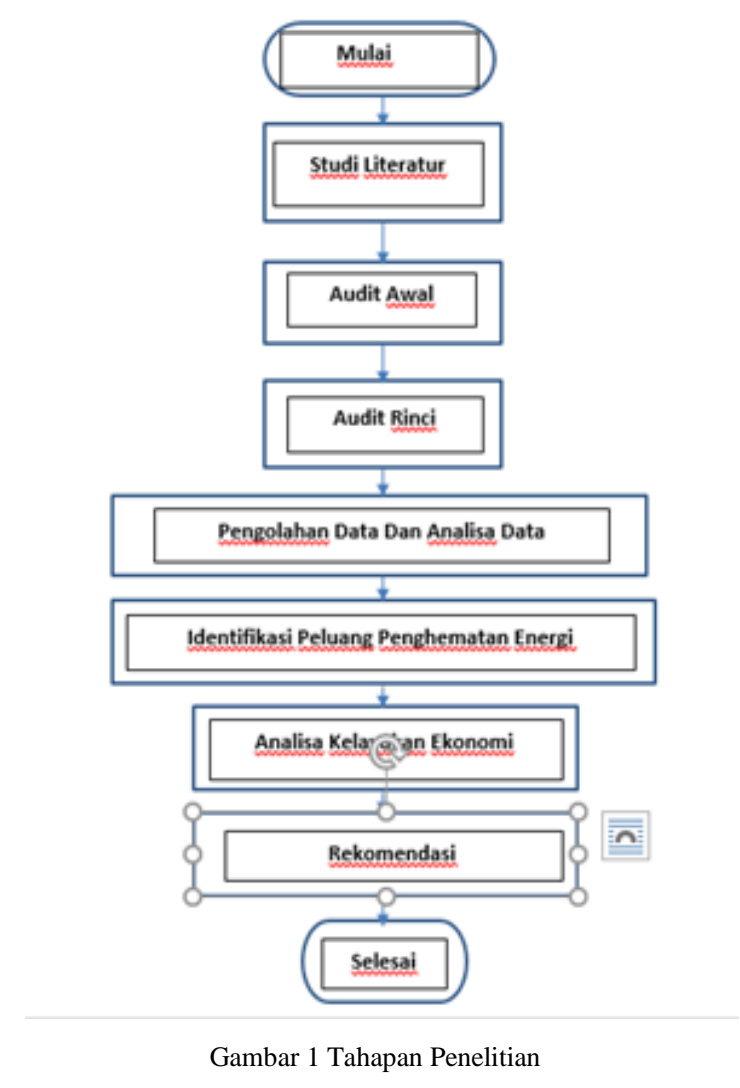

\section{HASIL DAN PEMBAHASAN}

\section{III.1 Data Survey}

* Data Metode Langsung

Pengukuran parameter untuk perhitungan efisiensi boiler unit 3 di PT.Indo Bharat Rayon dengan metode langsung dilakukan pada 1 Oktober 2019 hasil pengukuran dapat ditunjukkan pada tabel III-1.

TABel III.1 Parameter Efisiensi Boiler (Metode Langsung)

\begin{tabular}{|l|l|l|l|c|}
\hline \multirow{2}{*}{NN$_{0}$} & \multicolumn{3}{|c|}{ Parameter } & \multirow{2}{*}{$\begin{array}{c}\text { Hasil } \\
\text { pengukuran }\end{array}$} \\
\cline { 2 - 4 } & Deskripsi & Satuan & simbol & \\
\hline 1 & Load/Beban & $\%$ & - & 72,886 \\
\hline 2 & jumlah uap yang dihasillkan & Ton/jam & ṁsteam & 486,975 \\
\hline 3 & Temperature Steam & $\mathrm{C}$ & Tsteam & 62,566 \\
\hline 4 & Tekanan Steam & Bar & Psteam & 203,173 \\
\hline 5 & Temperature Feed water & $\mathrm{C}$ & Tfeedwater & 7,35 \\
\hline 6 & jumlah bahan bakar yang & Ton $/ \mathrm{jam}$ & mifuel & \\
\hline 7 & Eigunakan & $\mathrm{kj} / \mathrm{kg}$ & $\mathrm{Hg}$ & $3.385,99$ \\
\hline 8 & Entalphy Steam & $\mathrm{kj} / \mathrm{kg}$ & $\mathrm{Hf}$ & $1.929,085$ \\
\hline 9 & Nilai kalor bahan bakar & $\mathrm{kCal} / \mathrm{kg}$ & GCVfuel & 4.300 \\
\hline 10 & Nilai kalor bahan bakar & $\mathrm{kj} / \mathrm{kg}$ & GCVfuel & 18003,24 \\
\hline
\end{tabular}

\section{* Data Metode Tidak Langsung}

Pengukuran parameter untuk perhitungan efisiensi boiler unit 3 di PT.Indo Bharat Rayon dengan metode tidak langsung dilakukan pada 1 Oktober 2019 hasil pengukuran dapat ditunjukkan pada tabel III-2. 
TABel III.2 PARAmeter EFISIENSI BoILER (Metode TIDAK LANGSUNG)

\begin{tabular}{|c|c|c|c|}
\hline No & Parameter & Nilai & satuan \\
\hline 1 & fuel firing rate & 33,367 & Ton/jam \\
\hline 2 & steam generation rate & 72,886 & Ton/jam \\
\hline 3 & Psteam & 62,566 & $\mathrm{~kg} / \mathrm{cm}^{3}(\mathrm{~g})$ \\
\hline 4 & Tsteam & 486,9752 & c \\
\hline 5 & Tfeedwater & 203.095 & c \\
\hline 6 & $\% \mathrm{CO}_{2}$ & 13 & $\%$ \\
\hline 7 & $\% \mathrm{CO}$ & 0 & $\%$ \\
\hline 8 & $\% 02$ & 9,6 & $\%$ \\
\hline 8 & rata2 Thlue gas & 148,5 & C \\
\hline 9 & Tambient & 32 & C \\
\hline 10 & humidity in ambient air & 0,023 & $\begin{array}{l}\mathrm{kg} / \mathrm{kg} \quad \text { dry } \\
\text { air }\end{array}$ \\
\hline 11 & surface temperature of boiler & 54.7 & C \\
\hline 12 & $\begin{array}{l}\text { wind velocity around the } \\
\text { boiler }\end{array}$ & 3 & $\mathrm{~m} / \mathrm{s}$ \\
\hline 13 & total surface area of boiler & 2.666 & $\mathrm{~m}^{2}$ \\
\hline 14 & gcv bottom ash & 0,5 & $\mathrm{kCal} / \mathrm{kg}$ \\
\hline 15 & gcv fly ash & 12,2 & $\mathrm{kCal} / \mathrm{kg}$ \\
\hline \multirow[t]{2}{*}{16} & ratio of bottom ash & $70: 30$ & \\
\hline & \multicolumn{3}{|l|}{ fuel analysis in \% } \\
\hline 17 & ash content in fuel & 5,7 & $\%$ \\
\hline 18 & moisture in coal & 23,5 & $\%$ \\
\hline 19 & carbon content & 58.73 & $\%$ \\
\hline 20 & hydrogen content & 3,73 & $\%$ \\
\hline 21 & Nitrogen & 1 & $\%$ \\
\hline 22 & Sulfur & 0,3 & $\%$ \\
\hline 23 & Oxygen & 7 & $\%$ \\
\hline 24 & Gcv of coal & 4300 & $\mathrm{kCal} / \mathrm{kg}$ \\
\hline
\end{tabular}

\section{III.2 Pengolahan Data}

Berdasarkan data pengukuran metode langsung dan data pengukuran metode tidak langsung dan rumus - rumus pada bab 2, maka dapat dihitung parameter-parameter boiler, besarnya parameter- parameter dapat dirangkum pada tabel III.3 berikut.

TABel III.3 RAngkuman Hasil Perhitungan PARAmeter-Parameter PaDA Boiler

\begin{tabular}{|c|c|c|c|c|}
\hline NO & PARAMETER & 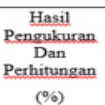 & $\begin{array}{c}\text { Spesifikasi } \\
\text { Efisiensi } \\
(\%)\end{array}$ & Keterangan \\
\hline 1 & $\begin{array}{l}\text { Efisiensi Boiler Dengan Metode } \\
\text { Langsung }\end{array}$ & 80,35 & \multirow{2}{*}{$86,3 \%$} & \multirow{2}{*}{$\begin{array}{l}\text { Efisiensi Boiler } \\
\text { sudah dibawah } \\
\text { spesifikasinya }\end{array}$} \\
\hline 2 & $\begin{array}{l}\text { Efisiensi Boiler Dengan Metode } \\
\text { Tidak Langsung }\end{array}$ & 79,683 & & \\
\hline 3 & $\begin{array}{l}\text { Heat loss karena gas buang kering } \\
\text { (L1) }\end{array}$ & 9,469 & & \\
\hline 4 & $\begin{array}{l}\text { Heat loss karena hidrogen dalam } \\
\text { bahan bakar (L2) }\end{array}$ & 4,969 & & \\
\hline 5 & $\begin{array}{l}\text { Heat loss karena kadungan air di } \\
\text { bahan bakar }(\mathrm{H} 2 \mathrm{O})(\mathrm{L} 3)\end{array}$ & 3,463 & & \\
\hline 6 & $\begin{array}{l}\text { Heat loss karena kandungan air di } \\
\text { udara } \mathrm{H} 2 \mathrm{O}(\mathrm{L} 4)\end{array}$ & 0.398 & & \\
\hline 7 & $\begin{array}{l}\text { Heat loss karena pembakaran } \\
\text { tidak sempurna (L5) }\end{array}$ & 0 & & \\
\hline 8 & $\begin{array}{l}\text { Heat loss karena radiasi } \\
\text { permukaan. konveksi. } \\
\text { tak terhitung (L6) }\end{array}$ & 1,875 & & \\
\hline 9 & Rugi-rugi dalam fly ash (L7) & 0,0048 & & \\
\hline 10 & $\begin{array}{l}\text { Heat loss } \\
\text { (bottom ash) } \\
\text { (L8) }\end{array}$ & 0,00046 & & \\
\hline
\end{tabular}

\section{III.3Peluang Penghematan Energi dan Analisis Kelayakan}

Berdasarkan Tabel III.3, dapat dilihat bahwa efisiensi boiler dengan metode langsung sebesar $80,35 \%$, sedangkan dengan metode tidak langsung sebesar 79,68\% nilai tersebut dibawah spesifikasinya yaitu $86,3 \%$, artinya performa/efisiensi boiler sudah mengalami penurunan. Untuk memperbaiki performa bolier dapat dilakukan dengan mengetahui besarnya rugi - rugi boiler. Dari tabel tersebut dapat dilihat bahwa rugi - rugi terbesar terjadi pada rugi - rugi karena gas buang kering L1 sebesar 9,469 $\%$. Rugi - rugi ini disebabkan karena pembakaran tidak sempurna, sehingga untuk meningkatkan efisiensi boiler dengan memperbaiki pembakarannya menjadi pembakaran sempurna.

Berdasarkan perhitungan nilai excess air daripada boiler sebesar $84,21 \%$, dan kandungan O2 sebesar 9,6\%, sedangkan untuk boiler berbahan batubara agar terjadi pembakaran sempurna maka standart excess air yang diizinkan sebesar 15 - $20 \%$ atau kandungan $\mathrm{O} 2$ sebesar 3-3,5 \%. Hal ni menunjukkan bahwa adanya kelebihan udara yang terlalu banyak dan menyebabkan bahan bakar boros, ini berarti bahwa efisiensi pembakaran tidak efisien dan mengakibatkan panas yang seharusnya terkumpul pada ruang pembakaran terbuang ke bagian stack. Hal ini memperlihatkan bahwa jumlah bahan bakar batubara yang dibutuhkan untuk menghasilkan panas yang sama lebih besar dibandingkan dengan kondisi antara oksigen dan $\mathrm{CO} 2$ yang efisien.

Untuk mendapatkan pembakar sempurna pada Boiler dengan memasang kontol Otomatis pada system pembakaran pada boiler, yaitu dengan memasang sensor pada gas buang boiler dan memasang inverter/VSD pada masukkan motor listrik penggerak fan/blower yang mensuplai udara masuk pada ruang bakar. Jika terjadi kelebihan udara atau Oksigen maka sensor akan memberikan informasi kepada kontroler / inverter untuk memperlambat putaran motor/ blower sehingga udara yang masuk ke ruang bakar mengecil. Jika masukan udara / oksigen sudah sesuai dengan spesifikasi pembakaran sempurna maka putaran motor konstan, dan sebaliknya jika pada pembakaran terjadi kekurangan udara maka sensor akan memberikan informasi pada kontroler/inverter untuk menggerakkan motor lebih cepat dan jika udara pembakaran sudah memcapai pembakaran sempurna maka kecepatan motor menjadi konstan.

Untuk memasang alat tersebut maka perlu dilakukan analisa kelayakannya, untuk menghitung kelayakan perlu diketahui saving energy yang didapatkan dan besarnya investasinya. Perhitungan kelayakan dapat dijabarkan sebagai berikut.

Perhitungan sebelum dilakukan konservasi atau pemasangan flue gas analyzer/combustion optimizer :

1. Kelebihan udara yang disuplai (Excess =Air)

$\%$ suplai udara berlebih $=\frac{\% O 2}{(21-\% 02)} \times 100 \%$

$=\frac{9,6}{(21-9,6)} \times 100 \%=\mathbf{8 4 , 2 1 \%}$

2. Massa aktual udara yang disuplai/kg bahan bakar (AAS)

$\begin{aligned} \text { AAS } & =(1+\mathrm{EA} / 100) \times \text { udara teorit } \\ & =(1+84,21 / 100) \times 7,819 \\ & =\mathbf{1 4}, \mathbf{1 9 6} \mathbf{~ k g} / \mathbf{k g} \text { batubara }\end{aligned}$

3. Heat loss karena gas buang kering ( L1)

$$
\begin{aligned}
& L 1=\frac{\mathrm{m} \times C p \times\left(T_{f}-T_{a}\right)}{G C V \text { batu bara }} \times 100 \\
& \quad \frac{\left(14,196+1 \frac{\mathrm{kg}}{\mathrm{kg}} \text { of fuel }\right) \times 0,23 \times(148,5-32)}{4300} \\
& =\mathbf{9 , 4 6 9} \% \\
& \mathrm{Cp}=\text { Kalor jenis gas buang }(0,23 \mathrm{kCal} / \mathrm{kg})
\end{aligned}
$$

\section{Efisiensi Boiler Sebelum Konservasi}

$(\eta)=100-(\mathrm{L} 1+\mathrm{L} 2+\mathrm{L} 3+\mathrm{L} 4+\mathrm{L} 5+\mathrm{L} 6+\mathrm{L} 7+\mathrm{L} 8)$

$=100-(9,469+4,969+3,463+0,398+0+1,875+0,00480$ $+0,00046)=\mathbf{7 9 , 6 8 3}$

Perhitungan setelah dilakukan konservasi atau pemasangan flue gas analyzer/combustion optimizer

1. Kelebihan udara yang disuplai (Excess Air)

$\%$ suplai udara berlebih

$$
\begin{aligned}
& =\frac{\% 02}{(21-\% 02)} \times 100 \% \\
& \quad=\frac{3}{(21-3)} \times 100 \%=16,7 \%
\end{aligned}
$$

2. Massa aktual udara yang disuplai/ $\mathrm{kg}$ bahan bakar (AAS)

AAS $=(1+\mathrm{EA} / 100) \times$ udara teoritis

$$
=(1+16,7 / 100) \times 7,819
$$$$
=8,99 \mathrm{~kg} / \mathrm{kg} \text { batubara }
$$ 
3. Heat loss karena gas buang kering ( L1)

$$
\begin{aligned}
& \begin{array}{l}
L 1=\frac{\mathrm{m} x \operatorname{Cp} x\left(T_{f}-T_{a}\right)}{G C V \text { batu bara }} \times 100 \\
=\frac{\left(\text { AAS }+ \text { massa bahan bakar dipasok) } x C p x\left(T_{f}-T_{a}\right)\right.}{G C V \text { batu bara }} \times 100
\end{array} \\
& =\frac{\left(14,196+1 \frac{\mathrm{kg}}{\mathrm{kg}} \text { of fuel }\right) \times 0,23 \times(148,5-32)}{4300} \times 100=\mathbf{6 , 2 3} \%
\end{aligned}
$$

$\mathrm{Cp}=$ Kalor jenis gas buang $(0,23 \mathrm{kCal} / \mathrm{kg})$

4. Efisiensi Boiler Setelah Konservasi

$$
\begin{aligned}
& \text { Efisiensi Boiler }(\eta)=100-(\mathrm{L} 1+\mathrm{L} 2+\mathrm{L} 3+\mathrm{L} 4+\mathrm{L} 5+\mathrm{L} 6 \\
& +\mathrm{L} 7+\mathrm{L} 8) \\
& =100-(6,23+4,969+3,463+0,398+0+1,875+0,00480 \\
& +0,00046)=\mathbf{8 3 , 0 6} \%
\end{aligned}
$$

TABEL IV.4 ANALISA KelayaKan EKonomi PEMASANGAN COMBUSTION OPTIMIZER

\begin{tabular}{|r|l|c|r|}
\hline \multicolumn{5}{|c|}{ ANALISA KELAYAKAN EKONOMI PEMASANGAN COMBUSTION OPTIMIZER } \\
\hline No & \multicolumn{1}{|c|}{ Keterangan } & Satuan & \multicolumn{1}{c|}{ Nilai } \\
\hline 1 & Konsumsi Batubara Sebelum Konservasi & $\mathrm{kg} / \mathrm{jam}$ & 7350 \\
\hline 2 & Efisiensi Sebelum Konversi & $\%$ & 79,683 \\
\hline 3 & Efisiensi Sebelum Konversi & $\%$ & 83,06 \\
\hline 4 & Perbaikan Efisiensi & $\%$ & 3,377 \\
\hline 5 & Penghematan Batu Bara & $\mathrm{kg} / \mathrm{jam}$ & 248,2 \\
\hline 6 & Konsumsi Batubara Setelah Konservasi & $\mathrm{kg} / \mathrm{jam}$ & $7.101,8$ \\
\hline 7 & Operasi Boiler Per Tahun & Jam & 8.760 \\
\hline 8 & Penghematan Batu Bara/tahun & $\mathrm{kg} /$ Tahun & $2.174 .315,2$ \\
\hline 9 & Harga Batu Bara Per kg & $\mathrm{Rp} / \mathrm{kg}$ & 531,2 \\
\hline 10 & Penghematan Batu Bara/tahun & $\mathrm{Rp} /$ Tahun & $1.155 .017 .988,0$ \\
\hline 11 & Investasi Alat & $\mathrm{Rp}$ & 150.000 .000 \\
\hline 12 & Break Even Point & Bulan & 1,6 \\
\hline 13 & NPV ( $\mathrm{n}=10$ tahun, I =0\%= biaya sendiri) & $\mathrm{Rp}$ & $11.400 .179 .880,2$ \\
\hline 14 & Kelayakan & & Layak \\
\hline
\end{tabular}

Berdasarkan analisa kelayakan pada tabel IV.4 diatas pemasangan Combustion Optimizer pada boiler layak dilakukan karena mempunyai nilai NPV yang positif.

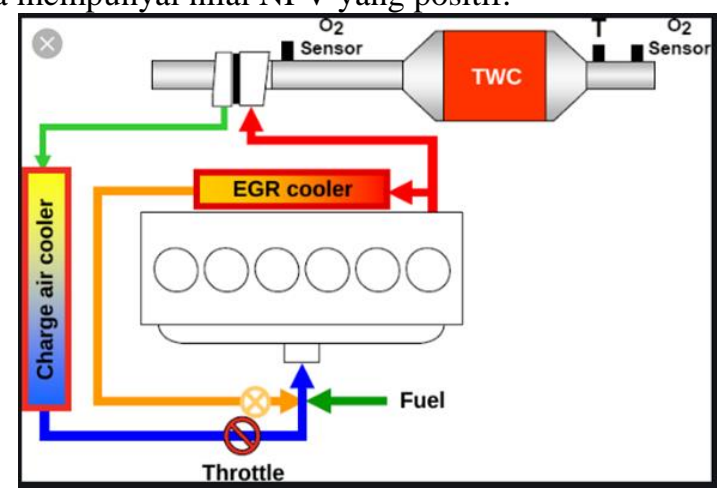

Gambar 2 Ilustrasi pemasangan sensor flue gas analyzer/Combustion Optimizer

Pengurangan losses pada flue gas membutuhkan investasi berupa 1 set combustion optimizer yang terdiri dari, sensor oxygen detector, controller, dan variable speed drive yang nantinya terhubung dengan fan untuk air intake ke ruang pembakaran.

\section{KESIMPULAN}

Efisiensi boiler dengan menggunakan metode langsung sebesar $80,35 \%$. Dan efisiensi boiler dengan menggunakan metode tidak langsung sebesar 79,683\%.
Spesifikasi efisiensi boiler sebesar 86,3\%, sehingga performa/efisiensi boiler sudah turun. Untuk menaikkan performa/efisiensi boiler dengan memasang Combustion Optimizer.

Pemasangan Combustion Optimizer layak dilakukan, karena nilai NPV sebesar Rp 11.400.179.880,2 dengan Break Even Point 1,6 bulan, dan Saving Energi sebesar Rp 1.155.017.988,0/ tahun. Dan dengan Investasi yang yang dibutuhkan untuk Combustion Optimizer sebesar Rp 150 Juta.

\section{DAFTAR PUSTAKA}

[1] ESDM. 2012.Peraturan Menteri ESDM RI No 14 Tahun 2012.

[2] Turner,W\&Steve Doty.2006.Energy Management Handbook. Sixth Edition.John Wiley \& Sons,Ltd.

[3] Pedoman Efisiensi Energi Asia.2015. Boiler dan Pemanas Fluida Termis.www.energyefficiencyasia.com. (akses 23 Mei 2019)

[4] Ginting,R.2006.Ekonomi Teknik . Medan .Universitas Sumatera.

[5] Badan Pengkajian Dan Penerapan Teknologi .Balai Besar Teknologi Energi.Prosedur Standar Dan Teknik Audit Energi Di Industri.ISBN 978-602-1124-88-8. Jakarta. 2015.

[6] Departemen Pertambangan Dan Energi. Prosedur Audit Energi Pada Bangunan Gedung. Jakarta.

[7] TUV NORD.Upgrading And Leveraging Indonesia To Fortify Energy Efficiency Through Academic And Technical Trainings For Energy Management Professionals.Jakarta.2013.

[8] UNIDO. Expert Training On Steam System Optimization.Jakarta.2015

[9] HAKE. Materi Pembekalan Uji Kompetensi/Sertifikasi Auditor Energi Industri. Jakarta. 2013.

[10] CIPEC. Energy Efficiency Planning And Management Guide. ISBN 0-662-31457-3.Her Majesty The Queen In Right Of Canada.2002. 